\title{
LIVESTOCK PRODUCTION AND DIFFUSE POLLUTION IN A VOLCANIC SOIL
}

\author{
Marta Alfaro and Francisco Salazar \\ National Institute for Agricultural Research (INIA), Remehue Research Centre, PO Box \\ 24-0, Osorno, Chile. Corresponding author: malfaro@inia.cl \\ Producción animal y contaminación difusa en un suelo volcánico
}

Key words: Nitrogen, phosphorus, dairy production, beef production, environmental impact

\begin{abstract}
In developed countries, intensive grazing has been related to water pollution. The results of several projects carried out on a volcanic soil of the Osorno soil series on beef grazing production systems have shown that grazing management did not increase total nitrogen (N) and phosphorus (P) transfer and losses. Due to the high water infiltration capacity of the soil, runoff was $<1 \%$ of total drainage, therefore, $\mathrm{N}$ and $\mathrm{P}$ losses in runoff were small. Nitrogen leaching losses were high ( 3 up to $71 \mathrm{~kg} \mathrm{~N} \mathrm{ha}^{-1} \mathrm{yr}^{-1}$ ). Nitrogen loss in runoff was mainly lost as DON (c. 50\%) while $\mathrm{N}$ leaching losses were mainly as nitrate (c. 70\%). Total $\mathrm{P}$ losses ranged between 1 and $22 \mathrm{~g} \mathrm{P} \mathrm{ha}^{-1} \mathrm{yr}^{-1}$ and they increased with increasing field slopes. Phosphorus was mainly lost as reactive $\mathrm{P}(c .70 \%)$. Total losses were greatly affected by incidental $\mathrm{N}$ and $\mathrm{P}$ losses associated to spring $\mathrm{N}$ and $\mathrm{P}$ fertilizer application, so that grassland managements should consider this constrain for grazed areas in southern Chile. Research should be carried out in more intensive production systems (e.g. dairy farms) where $\mathrm{N}$ and $\mathrm{P}$ rates used are higher and applied during different times of the year, with a potential impact for the wider environment.
\end{abstract}


Palabras claves: nitrógeno fósforo, producción de leche, producción de carne, impacto medioambiental

\section{RESUMEN}

En países desarrollados, el pastoreo intensivo ha sido relacionado con la contaminación de aguas. Resultados de distintos proyectos llevados a cabo en un andisol de la serie Osorno, en sistemas de producción de carne bajo pastoreo, han demostrado que el manejo del pastoreo no incrementó la transferencia y las pérdidas de nitrógeno $(\mathrm{N})$ y fósforo $(\mathrm{P})$. Debido a la alta capacidad de infiltración de agua del suelo, el arrastre superficial fue menos del $1 \%$ del drenaje total, por lo que las pérdidas de $\mathrm{N}$ y $\mathrm{P}$ en arrastre superficial fueron bajas. Las pérdidas de $\mathrm{N}$ por lixiviación fueron altas ( 3 hasta $71 \mathrm{~kg} \mathrm{~N} \mathrm{ha}^{-1}$ año $\left.^{-1}\right)$. Las pérdidas de $\mathrm{N}$ en arrastre superficial fueron principalmente como NOD (c. 50\%), mientras que las pérdidas de $\mathrm{N}$ por lixiviación fueron principalmente como nitrato (c. $70 \%$ ). Las pérdidas totales de $\mathrm{P}$ variaron entre 1 y $22 \mathrm{~g} \mathrm{P} \mathrm{ha}^{-1} \mathrm{año}^{-1}$ y se incrementaron con incrementos en la pendiente del terreno. El P se perdió principalmente en su forma disponible (c. 70\%). Las pérdidas totales fueron fuertemente afectadas por las pérdidas incidentales de $\mathrm{N}$ y $\mathrm{P}$ asociadas a la aplicación de fertilizantes en primavera, de manera tal que el manejo de praderas debería considerar esta limitación en áreas bajo pastoreo en el sur de Chile. La investigación en este ámbito debería realizarse en sistemas más intensivos de producción (e.g. lecherías) donde las dosis de $\mathrm{N}$ y $\mathrm{P}$ usadas son mayores y aplicadas en distintas épocas del año, con un potencial de impacto para el medio ambiente.

\section{INTRODUCTION}

The L ake and the River R egions of southern Chile (39 to 43ㅇ, 710 to $740 \mathrm{~W}$ ) have suitable climatic conditions and soil types for cattle production. Consequently, this area produces $65 \%$ of the country's milk and $45 \%$ of its meat, based on grazed on natural and improved pastures (INE, 2001). Volcanic soils are widespread in this area, being characterised by low nutrient availability and high phosphorus $(\mathrm{P})$ fixation capacity (Escudey et al., 2001), so that this fact has created the perception that low $\mathrm{P}$ losses to waters can be expected in the area. The use of nitrogen $(\mathrm{N})$ and $\mathrm{P}$ in fertilizers and animal feed in the area has increased over the last ten years (Alfaro \& Salazar, 2005), being these elements the main cost of fertilizer application. This intensification has resulted in greater stocking rates being used in direct grazing and a higher demand for forage for grazing animals.

In developed countries the environmental impact of livestock systems has been widely studied, because of the important role of this activity on water, soil and air pollution (Jarvis \& Oenema, 2000). In countries of occidental Europe has been estimated that agriculture contributes with 37 to $82 \%$ of the $\mathrm{N}$ and with 27 to $38 \%$ of the $\mathrm{P}$ input into surface waters (Isermann, 1990).

Despite the importance of livestock production in southern Chile and that $\mathrm{N}$ and $\mathrm{P}$ are strategic for grassland production in the area, the potential effect of grazing systems on diffusse pollution in the area has not been estimated, even though other relevant economic activities in the southern region are aquaculture and tourism.

\section{MATERIALS AND METHODS}

Over the last four years, INIA Remehue $\left(40^{\circ} 35^{\prime} \mathrm{S}, 73^{\circ} 12^{\prime} \mathrm{W}\right)$ has carried out several research studies to estimate $\mathrm{N}$ and $\mathrm{P}$ transfer and losses from beef grazing systems based on permanent pastures in an andisoil of the Osorno soil series (Typic Hapludands; CIREN 2003). All experiment were tested 
on closed systems managed under rotational grazing on a 25 years old permanent pasture with Black and White Friesian steers (50$75 \%$ Holstein) with initial live weights for the three years of c. $220 \pm 0.5 \mathrm{~kg}$. The main species in the pasture were Lolium perenne, Dactylis glomerata and Holcus lanatus. Treatments were fertilized in autumn with $45 \mathrm{~kg} \mathrm{~N}^{-1}$ (urea, $46 \% \mathrm{~N}$ or sodium nitrate, $16 \% \mathrm{~N}$ ) and spring $22.5 \mathrm{~kg} \mathrm{~N} \mathrm{ha}^{-1}$ (sodium nitrate, $16 \% \mathrm{~N}$ ) and $40 \mathrm{~kg} \mathrm{P} \mathrm{ha}{ }^{-1}$ (triple superphosfate, TSP, $46 \% \quad \mathrm{P}_{2} \mathrm{O}_{5}$ ).

\section{Nitrogen losses}

To quantify $\mathrm{N}$ losses in surface runoff, three surface lysimeters $(5 \times 5 \mathrm{~m})$ were established in each closed treatment, according to the methodology described by Alfaro \& Salazar (2007). The accumulated runoff was measured three times per week and runoff samples were stored at $4^{\circ} \mathrm{C}$ until analysis for available N. Nitrate was measured using the salicylic acid method (Robarge et al., 1983), ammonium was determined through the indophenol methodology (Mulvaney, 1996) and total $\mathrm{N}$ was determined with the macro-Kjeldahl method (Mé thod 10071 test 'N Tube; $\left.{ }^{\circledR} H a c h, 2000 a\right)$. Organic N was calculated as the difference between total $\mathrm{N}$ and the sum of the available $\mathrm{N}$ forms. Nitrogen leaching losses were determined using the ceramic suction cups technique described by Lord \& Shepherd (1993), which has been shown to be suitable for freely draining soils (Webster et al., 1993). Ceramic cups were placed at a depth of 60 $\mathrm{cm}$ in the soil (three replicates per surface lysimeter) at an angle of $30^{\circ}$ to the vertical. Samples were stored at $-15^{\circ} \mathrm{C}$ until analysis for available $\mathrm{N}\left(\mathrm{N}-\mathrm{NO}_{3}{ }^{-}\right.$and $\left.\mathrm{N}-\mathrm{NH}_{4}{ }^{+}\right)$in a Skalar autoanalyser. Total $\mathrm{N}$ losses were calculated as the product of drainage and $\mathrm{N}$ concentration in the respective samples. Drainage between the sampling periods was estimated by subtracting potential evapotranspiration figures from rainfall using meteorological data collected close to the experimental site $(<1 \mathrm{~km})$. Evapotranspiration for the sward was calculated using the Penman-Monteith method (Penman, 1948). The amount of ammonium and nitrate leached over the period was then calculated according the trapezoidal rule proposed by Lord \& Shepherd (1993).

\section{Phosphorus losses}

To quantify $\mathrm{P}$ losses in surface runoff, the three surface lysimeters were used following the methodology described for $\mathrm{N}$ determinations. Reactive P (RP) was measured using the ascorbic acid method (Clesceri et al., 1998), and total $\mathrm{P}$ was determined through the digestion with acid persulphate (method $\left.8190{ }^{\circledR} H a c h, 2000 b\right)$. Organic P (OP) was estimated as the difference between TP and RP for each sample, so that this data may also include particulate P. Total P losses were calculated as the product of drainage and $P$ concentration in the respective samples.

\section{RESULTS AND DISCUSSION}

\section{Weather and rainfall}

During 2004, total rainfall was 1,231 mm, similar to that of the 30 years average for the area. Both 2005 and 2006 had a surplus equivalent to 195.3 and $176.0 \mathrm{~mm}$ of rainfall, respectively, in relation to a 30 years average. Average rainfall over the drainage period was $49 \%$ and $52 \%$ greater during 2005 and 2006 in relation to 2004 , respectively. The greater rainfall of 2005 and 2006 had an impact on drainage values of those years, so that they were greater than drainage for 2004 (c. 600, 900 and 800 mm drainage for 2004, 2005 and 2006, respectively). 


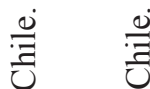

I

营 ज

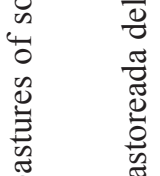

อี हี

苞 苞

స్త్ర

के क्ष

ฐ๐

$\underbrace{\frac{\pi}{2}}_{00}$

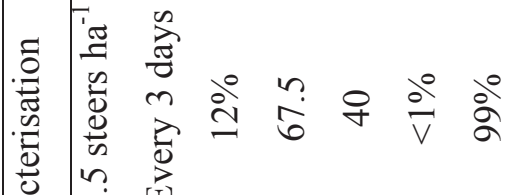

皇

芩

导

क

.

s

ह

至

年

ㄹ.

ฮี

o $\frac{0}{0}$

芯 웛

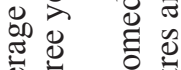

के

出

$\because$ 品

总 气
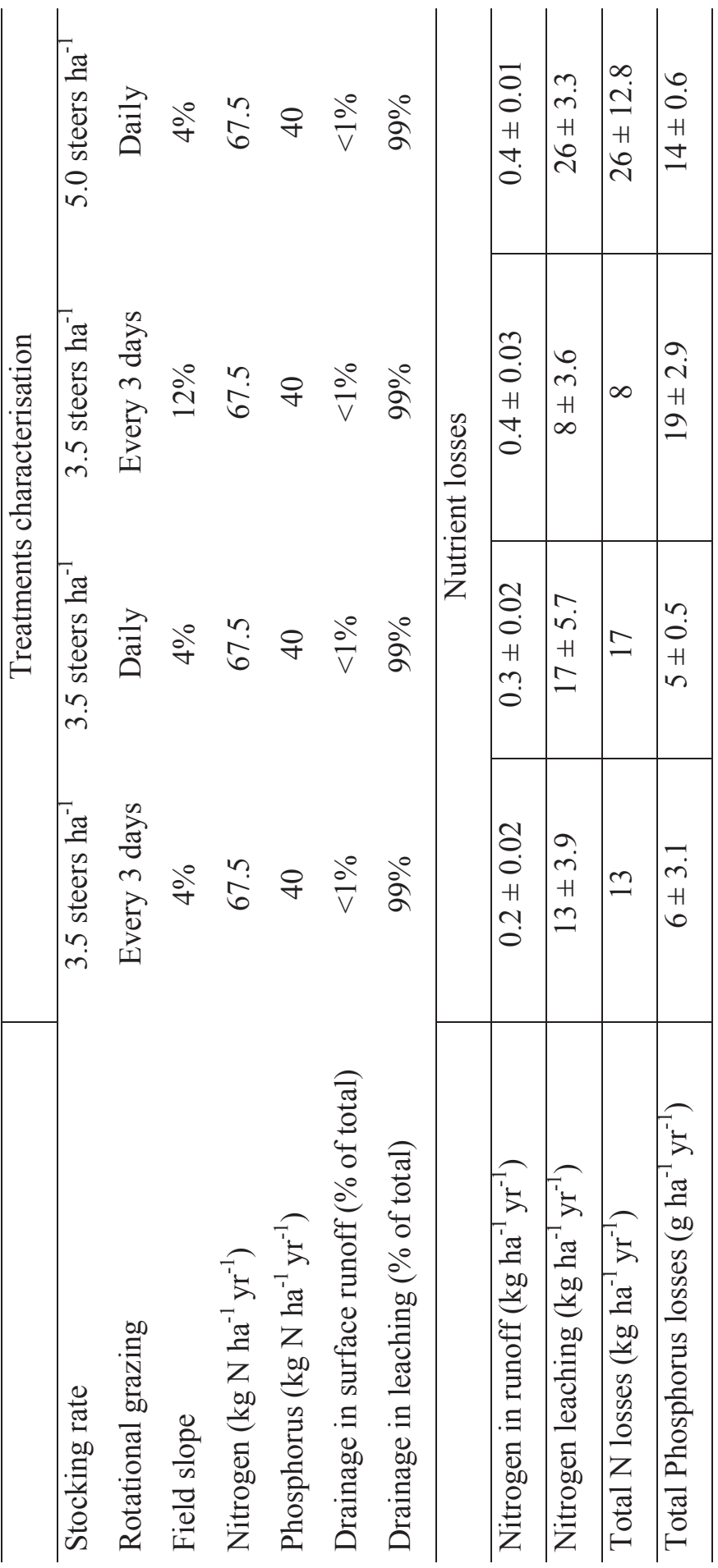


\section{Water pathways}

Results showed that the main pathway for water movement was leaching with $99 \%$ of total drainage, independently of the animal managent or the field slope $(\mathrm{P} \leq 0.05$; Table $1)$, which agrees with results of Ledgard et al., (1999) for leaching experiments carried out in dairy systems on similar soils to that of the present study in New Zealand. Runoff results can be related to the low bulk density of the topsoil, favouring vertical infiltration capacity, in agreement with Dorel et al. (2000).

\section{Nitrogen losses}

Nitrate average concentration in surface runoff samples was higher than the $11.3 \mathrm{mg}$ $\mathrm{N} \mathrm{L}^{-1}$ established by the European Union for water consumption (i.e. 91/676/EC). Ammonium concentration in surface runoff samples was over the Chilean Directive for quality of surface continental waters (i.e. DS $87 / 01$ ) in more than $80 \%$ of the total samples analysed. Most of the sampling dates when nitrate and ammonium concentration in the surface runoff samples were high occurred during the winter period. This was probably related to the direct transport of nutrients, soil particles and faeces residues down the slope. Despite the high concentrations in runoff samples, total losses in runoff were low $\left(<0.5 \mathrm{~kg} \mathrm{~N} \mathrm{ha}^{-1}\right.$ $\left.\mathrm{yr}^{-1}\right)$. However, these data stress the importance of best fertilizer managent practices, because they imply a risk for incidental $\mathrm{N}$ losses and thus, for surface water pollution in areas located closed by grazing paddocks.

Of total $\mathrm{N}$ lost in runoff, ammonium and nitrate losses represented on average c. $25 \%$ each, as the result of urine lost in runoff immediately after excretion in each grazing and $\mathrm{N}$ lost after nitrate fertilizer application in spring time. Dissolved organic N (DON) represented c. $50 \%$ of total $\mathrm{N}$ lost in runoff. This could be related to the high soil organic matter content in the topsoil and the expected high soil biomass activity, in agreement with Jarvis (2002) and Alfaro et al. (2006). Concentrations of $\mathrm{NO}_{3}{ }^{-} \mathrm{N}$ at each sampling date for leaching did not exceed the EC limit of $11.3 \mathrm{mg} \mathrm{L}^{-1}$. Nitrogen leaching losses were variable for different years and ranged from c. 3 to $70 \mathrm{~kg} \mathrm{ha}^{-1} \mathrm{yr}^{-1}$. A high proportion (c. $70 \%$ ) of the $\mathrm{N}$ was leached as nitrate with ammonium averaging less than c. 10\% of the total inorganic $\mathrm{N}$ losses, in agreement with data reported by Webster et al. (1993) and Salazar et al. (2005). Dissolved organic $\mathrm{N}$ in leachates samples varied from 8 to 22.5 $\mathrm{kg} \mathrm{ha}^{-1} \mathrm{yr}^{-1}$, which represented c. $25 \%$ of total leaching losses. According to this, DON was the most important $\mathrm{N}$ form in $\mathrm{N}$ leaching losses after nitrate, as discussed previously.

\section{Phosphorus losses}

In all experiments, average $P$ concentrations measured in runoff samples (RP and OP) were much greater than the 50 and $25 \mu \mathrm{g}$ total $\mathrm{P} \mathrm{L}^{-1}$ established as eutrophication limit for rivers and lakes, respectively (Leinweber et al., 2002). Peaks of RP concentration were measured associated to spring $\mathrm{P}$ fertilizer application during all years. The high RP concentrations after TSP addition was probably because of the direct transport of fertilizers granules in runoff after the application and because they were rapidly solubilized by surface runoff (Heatwaite et al., 1998). Peaks of OP concentration were measured during spring and they were probably related to the flush of organic matter mineralization produced at that time, in agreement with Turner \& Haygarth (2000).

The main parameter affecting $\mathrm{P}$ losses was the field slope, so that P losses on a $4 \%$ slope field were 3 times lower than those on a $12 \%$ slope field (4 and $15 \mathrm{~g} \mathrm{P} \mathrm{ha}^{-1} \mathrm{y}$ $\mathrm{r}^{-1}$, respectively). Animal management (stocking rate, grazing pressure) did not increase $\mathrm{P}$ losses in runoff. Overall $\mathrm{P}$ losses were low when compared with results of $\mathrm{P}$ transfer from grazed land in Europe 
(Haygarth \& Jarvis, 1997) and New Zealand (McColl et al., 1977). Total losses were mainly found as RP losses ( $70 \%$ on average), in agreement with Sharpley \& Rekolainen (1997). Organic P losses represented only $30 \%$ of the total $\mathrm{P}$ lost in runoff. Because of the high $\mathrm{N}$ and $\mathrm{P}$ concentrations measured in this study in runoff samples collected from a volcanic soil, best management practices (BMP) in relation to the timing of $\mathrm{N}$ and $\mathrm{P}$ fertilizer application should be adopted in the area, avoiding nutrients addition during the winter period or high rainfall events.

\section{CONCLUSIONS}

Overall losses in surface runoff were low due to the low amount of runoff measured, because the high infiltration capacity of the Andisol in the topsoil layer. Nitrogen leaching losses were high, ranging from $c$. 3 to $70 \mathrm{~kg} \mathrm{~N} \mathrm{ha}^{-1} \mathrm{yr}^{-1}$. Nitrogen lost in runoff was mainly as DON (c. 50\%). Nitrogen lost by leaching was mainly as nitrate (c. 70\%). Phosphorus was mainly lost as reactive $\mathrm{P}$ (c. $70 \%)$.

These results showed that there is room for the intensification of beef grazing systems through grazing management, but that an adequate fertilizer management is required at all times during the year to reduce incidental $\mathrm{N}$ and $\mathrm{P}$ losses in runoff, especially in sloppy soils.

Research should be carried out in more intensive production systems where $\mathrm{N}$ and $P$ rates used are higher and applied at different times of the year, representing a potential impact for the wider environment. In addition, we think that systems evaluation for cattle production should consider other losses as well, which includes gaseous emissions, that has been an important pathway of nutrient losses in these systems worldwide.

\section{AKNOWLEDGMENT}

To the International Foundation for Science (IFS) and to the Organisation for the Prohibition of Chemical Weapons, The Hague (OPCW) (IFS Grant W/3550-1) and to FONDECYT (Grant 1040104) for funding this research. Also thanks to the Grassland and Environmental Research team at INIA Remehue.

\section{LITERATURA CITADA}

ALFARO, M. Y SALAZAR, F. 2005. Ganadería y contaminación difusa, implicancias para el sur de Chile. Agric. Tec. (Chile) 65: 330-340.

ALFARO, M.A.; SALAZAR, F.J.; ENDRESS, D.; DUMONT, J.C. AND VALDEBENITO, A. 2006. Nitrogen leaching losses on a volcanic ash soil as affected by the source of fertiliser. J. Soil Sc. Plant Nutr. 6: 54-63. ALFARO, M. A. AND SALAZAR, F. J. 2007. Phosphorus losses in surface runoff from grazed permanent pastures on a volcanic soil from Chile. Soil Use Manage. 23: 323-327.

CIREN, 2003. Descripciones de suelos, materiales y símbolos, estudio agrológico X Región Vol. II, Centro de Información de Recursos Naturales Santiago, Chile.

CLESCERI, L.; GREENBERG, A. AND EATON, A. (EDS.). 1998. Standard Methods for the Examination of Water and Wastewater. 20th ed. American Public Health Association; American Water Works Association; Water Environment Federation. Washington, USA. Pág. Irreg.DOREL, M., ROGERESTRADE, J., MANICHON, H. AND DELVAUX, B. 2000. Porosity and soil water properties of Caribbean volcanic ash soils. Soil Use Manage. 16: 133140. 
DOREL, M., ROGER-ESTRADE, J., Manichon, H. \& Delvaux, B. 2000. Porosity and soil water properties of Caribbean volcanic ash soils. Soil Use Manage. 16: 133-140.

EC (EUROPEAN COMMUNITY). 1991. Council directive concerning the protection of water against pollution caused by nitrates from agricultural sources. Official Journal of the European Community (91/676/EEC), Legislation 1375/1-375/8.

ESCUDEY, M., GALINDO, G., FÖRSTER, J., BRICEÑO, M., DIAZ, P. \& CHANG, A. 2001. Chemical forms of phosphorus of volcanic ash-derived soils in Chile. Comm. Soil Sc. Plant Anal. 32: 601-616.

$\mathrm{HACH}, 2000 \mathrm{a}$. Procedures Manual Colorimeter DR/890 for total $\mathrm{N}$ determination. Hach Company Baltimore USA.

$\mathrm{HACH}$, 2000b. Procedures Manual Colorimeter DR/890 for total $P$ determination. Hach Company Baltimore USA.

HAYGARTH, P.M. \& JARVIS, S.C. 1997. Soil derived phosphorus from grazed grassland lysimeters. Water Res. 31: 140-148.

HEATHWAITE, A.L., GRIFFITHS, P. \& PARKINSON, R.J. 1998. Nitrogen and phosphorus in runoff from grassland with buffer strips following application of fertilisers and manures. Soil Use Manage. 14: 142-148.

INE. 2001. Estudio de la ganaderí a bovina en las Provincias de Valdivia, Osorno y Llanquihue. 65 p. Instituto Nacional de Estadí sticas, Santiago, Chile.

ISERMANN, K. 1990. Share of agriculture in nitrogen and phosphorus emissions into the surface waters of Western Europe against the background of their eutrophication. Fert. Res. 26: 253-269.
JARVIS, S.C. 2002. Environmental impacts of cattle housing and grazing. p. 10-23. In Kaske, M., H. SCHOLZ AND M. HÖLTERSHINKEN (EDS.). Recent developments and perspectives in bovine medicine. Keynotes lectures of the $22^{\text {nd }}$ World Buiatrics Cong. (WBC), Hannover, Germany. 18-23 August. WBC, Hannover, Germany.

JARVIS, S.C., AND O. OENEMA. 2000. Measuring and monitoring nitrogen and phosphorus flows and losses in grassland systems. p. 305-325. In Mannetje, L't and R.M. Jones (eds.). Field and laboratoty methods for grassland and animal production research. CAB International, Cambridge, UK.

LEINWEBER, P., TURNER, B.L. \& MEISSNER, R. 2002. Phosphorus. In: Agriculture, Hydrology \& Water quality (eds P. Haygarth \& S. Jarvis), Cab International Wallingford UK, pp. 2956.

LEDGARD, S.F., J.W. PENNO \& M.S. SPROSEN. 1999. Nitrogen inputs and losses from clover/grass pastures grazed by dairy cows, as affected by nitrogen fertilizer application. J. Agric. Sc., Cambridge 132: 215-225.

LORD, E.I. AND SHEPHERD, M.A. 1993. Development in the use of porous ceramic cups for measuring nitrate leaching. J. Soil Sc. 44: 435-449.

MCCOLL, R.H.S., WHITE, E. \& GIBSON, A.R. 1977. Phosphorus and nitrate runoff in hill pasture and forest catchments, Taita, New Zealand. New Z. J. Marine Fresh Water Res. 11: 729744.

MULVANEY, C.S. 1996. Nitrogeninorganic forms. In: Methods of soil Analysis: Chemical Methods, part 3 (eds. D. L. Sparks \& J. M. Bartels), pp: 1152:1155. Soil Science Society of America, American Society of Agronomy. Madison, Wisconsin, USA. 
PENMAN, H.L. 1948. Natural evaporation from open water, beare soil and grass. Proc. Roy. Soc., London A193: 120146.

ROBARGE, W.P., A. EDWARDS \& B. JOHNSON. 1983. Water and waste water analysis for nitrate via nitration of salicylic acid. Comm. Soil Sc. Plant Anal. 14:1207-1215.

SALAZAR, F.; ALFARO, M.; TEUBER, N.; IRAIRA, S.; VILLARROEL, D. AND RAMIREZ, L. 2005. Pé rdidas de nitrógeno por arrastre superficial y lixiviación en sistemas de producción de carne de la Décima Región. En: Libro de resúmenes de la XXX Reunión Anual de la Sociedad Chilena de Producción Animal. López, I y Sepúlveda, N. (eds.). 19-21 de octubre, Temuco, Chile. pp: 221-222.
SHARPLEY, A.N. \& REKOLAINEN, S. 1997. Phosphorus in agriculture and its environmental implications. In: Phosphorus loss from soil to water (eds H. Tunney, O. Carton, P. Brookes \& A. Johnston), CAB International Wallingford UK, pp. 1-53.

TURNER, B.L., AND P.M. HAYGARTH. 2000. Phosphorus forms and concentrations in leachates under four grassland soil types. Soil Sci. Soc. Am. J. 64: 1090-1099.

WEBSTER, C.P.; SHEPHERD, M.A.; GOULDING, K.W.T. AND LORD, E. 1993. Comparison of methods for measuring the leaching of mineral nitrogen from arable land. J. Soil Sc. 44: 49-62. 